\title{
Classification of traumatic integumentary tissue degloving
}

\author{
M.Yu. Korostelev, N.G. Shikhaleva, O.V. Klimov
}

Ilizarov National Medical Research Centre for Traumatology and Orthopedics, Kurgan, Russian Federation

\begin{abstract}
Introduction Detachment or sharp gross prolonged displacement of the skin, subcutaneous fatty tissue from the underlying fascia over more than $1 \%$ of the body surface with disorders of blood supply to these and sometimes underlying tissues results from high-energy mechanical action of various moving objects and force applied at an angle. Purpose to develop a classification of integumentary tissue detachments based on the variety of clinical types, severity, extent, combination of injuries with a possible quantitative assessment of their severity and extent. Methods Analysis of the literature and our own experience of treating 40 patients with detachments of integumentary tissues enabled to identify criteria for classifying patients into groups. Results A classification and rating scales were developed that reflect the area, depth of tissue damage, localization, general condition of the patient and the stage of the pathological process. Discussion The analysis of the literature on this topic showed that, to date, none of the proposed classifications is optimal. There is no clear definition of the area of compromised integumentary tissues relative to the entire surface of the human body. The issue of pathological process staging has not been reflected; damage and crushing of bones, muscle tissue, neurovascular formations have not been reflected; there is no clearly formulated algorithm for treating a patient depending on the stage and severity of tissue damage. Conclusion Application of the classification of integumentary tissue detachments which has been proposed enables to more objectively assess the nature of local tissue damage, taking into account the general condition of the patient.
\end{abstract}

Keywords: classification, soft tissue degloving, Morel-Lavallee lesion, extensive wounds

\section{INTRODUCTION}

Degloving or a sharp gross detachment of the skin, subcutaneous fat from the underlying fascia over more than $1 \%$ of the body surface with impaired blood supply to these and sometimes underlying tissues occurs due to gross high-energy mechanical actions of various moving objects [1]. I.G. Belenky et al [2] observed an extensive detachment of the integumentary tissues in $1.07-1.6 \%$ of the total number of patients with injuries. The authors state that their treatment is a difficult problem that has not been solved completely. Although degloving may occur anywhere in the body, the main areas of extensive detachment of integumentary tissues are the lower extremities, trunk, hands, scalp with variable magnitudes of skin and soft tissue loss [3-5]. Underestimation of the state of injured tissues or incorrectly chosen surgical tactics subsequently leads to extensive necrosis, purulent septic complications and even patient's disability $[6,7]$.

Purpose To analyze the available classifications of extensive degloving of integumentary tissues, to find their drawbacks, to develop a classification of integumentary tissue degloving based on the variety of clinical types, severity, extent, and combination of injuries.

\section{MATERIAL AND METHODS}

The work was carried out in the period from 2008 to 2017 at the trauma departments of the regional and city hospitals of Chelyabinsk and the Chelyabinsk region.

The studies were carried out in accordance with the ethical standards of the Declaration of Helsinki of the World Medical Association on the ethical principles for conducting scientific medical research with human involvement as amended in 2013 and the "Rules of Clinical Practice in the Russian Federation" approved by order of the Ministry of Health of the Russian Federation of June 19, 2003 No. 266 Patients signed informed consents for surgical intervention and publication of the obtained data without personal identification.

Forty patients were under observation, of whom 21 were females $(52.5 \%)$ and 19 males $(47.5 \%)$ including three children under 6 years old, three children from 7 to 17 years of age, ten were patients from 18 to 30 years old, six from 31 to 40 years, six from 41 to 50 , three from 51 to 60 and two were over 60 years of age. Thus, most of the patients were of working age. These injuries also happened in childhood and the older age group.

Distribution of patients by the mechanism of injury: 17 patients $(42.5 \%)$ had collision under a car wheel, $13(32.5 \%)$ hit a limb in a moving mechanism (dough mixer, rollers, transport belt), two (5\%) were dragged on an asphalted surface, three $(7.5 \%)$ had pressure injury of a limb and subsequent traction, three $(7.5 \%)$ had an a collision accident with a car, one had a blow and another one a dog bite $(2.5 \%)$. The numbers indicate that the main mechanisms of 
injuries with detachment of integumentary tissues was hitting a person under the wheels of a car and getting a limb into a moving mechanism.

Of the total number of patients, 14 subjects ( $28 \%$ ) were injured at work.

Damage to integumentary tissues up to $2 \%$ was revealed in 25 patients ( $62.5 \%$ of the total). In eight individuals $(20 \%)$, the detachment area ranged from 3 to $10 \%$. The most severe group was the third one with an affected area of more than $11 \%$ in seven subjects $(17.5 \%)$.

The distribution of patients according to skin damage: open degloving in 40 patients $(100 \%)$ and none had closed (Morel-Lavallée syndrome). Thus, the study presents an analysis of the treatment of only patients with open detachments of the integumentary tissues.
Based on the proposed classification of patients according to the depth of tissue damage, there were the following groups. Group 1 with skin and subcutaneous fat lesions were four patients (10\%); group 2 with lesions of the skin, subcutaneous fat and superficial fascia were eight subjects ( $20 \%$ ); group 3 with injured integumentary tissues and crushing of muscles were seven patients $(17.5 \%)$; group 4 had detachment of integumentary tissues, combined with injuries of neurovascular formations and bone tissue (fracture, bone defect) and comprised 21 cases (52.5\%).

After the injury, 12 patients were admitted in a state of shock. The conditions of moderate severity and a severe state were directly associated with the injury itself, concomitant injuries, and post-traumatic and hemorrhagic shock.

\section{RESULTS}

Based on the classification proposed below, all our patients were divided into groups: a mild type of integumentary tissue degloving was diagnosed in six cases $(12.5 \%)$, moderate severity was observed in seven cases $(17.5 \%)$, and 8 patients $(20 \%)$ had a severe type of degloving.

\section{DISCUSSION}

An analysis of the literature on the classification of extensive integumentary tissue degloving has been carried out. According to the literature, all types of skin degloving since the times of Morel-Lavallée (1863) (cited from John F. Carroll, 2010) [8] are usually divided into three groups: small, medium and large, but, unfortunately, without specifying the size of the area of separation. It was noted that the degloving may be open and closed. In the first case, there is a wound that communicates with the cavity at the separation site while in the second the skin is not completely damaged, although there may be quite extensive abrasions, but the cavity of the degloving does not communicate with them.

In 2013 I.E. Mikusev et al [9] published an updated classification of extensive traumatic soft tissue degloving, proposed in 1947 by V.K. Krasovitov [10]. The authors distinguish three main types of traumatic skin degloving. In the first type, crushing of the subcutaneous adipose tissue prevails in the separation zone with its division into areas associated with the skin, and the rest with the fascia. In the second type, the subcutaneous rupture of the adipose tissue comes in the first place, which is not accompanied by gross lesions in it and in deep-lying tissues, but most of the subcutaneous fat separates along with the skin. The third (mixed) type features areas of crushing of the subcutaneous fat alternate with areas where most of this fiber has been preserved along with the skin, like a layer (mixed, combined closed skin degloving). The proposed classification is based on morphological signs of lesion, does not take into account the area of compromised integumentary tissues, or existing crushing of deep-lying tissues, including bone, muscle tissue, and neurovascular formations.

A.A. Proshakov et al (1987) [11] divided all patients into 3 groups depending on the type, area of separation and treatment tactics. Group 1 is traumatic separation of the skin with an area of up to $200 \mathrm{~cm}^{2}$, increased limb volume, fluctuation; Group 2 has an area of $200-400 \mathrm{~cm}^{2}$, pain in the area of the injured segment, limb dysfunction, increaseв limb volume, decreased pulsation in the distal regions in severe edema, a symptom of undulation, the skin shifts into a fold (Keller's symptom); in group 3 the area of separation exceeds $400 \mathrm{~cm}^{2}$, the pathological process extends beyond one segment in most cases. This classification, apparently, applies only to adult patients, and it is difficult to use it in children and people of small stature, in whom the area of damage of up to $200 \mathrm{~cm}^{2}$ may lead to serious conditions.

V.N. Bordakov with a group of co-authors (2015) [2] also proposed to use the principles of classification into open and closed separation. They divide the lesions into limited (up to $200 \mathrm{~cm}^{2}$ ) and extensive (over $200 \mathrm{~cm}^{2}$ ). The third point is the type of degloving. The first type involves crushing of subcutaneous fatty tissue. A smaller part of it is associated with the skin, and the bigger one with the fascia. It is characterized by a complete disturbance of the blood supply to the skin due to the damage to the supplying vessels. The second type is the destruction of the subcutaneous fat. Most of it retains its 
connection with the skin, forming a rather thick layer containing a sufficient number of nutrient vessels.

Hidalgo D.A. [12] divides such injuries into three main groups. Type 1 is the most common type of avulsion injury and is the most common characterized by visible tears of the integumentary tissues in a limited area. Type 2 injuries are atypical torn injuries. At first glance, there are no serious signs of injury; however, in fact, there is an extensive tissue lesion (separation of tissue). Type 3 injury is referred to as torn skin in certain areas. These types of injuries include the plantar region and the scalp. Revascularization and replantation are required for most of these injuries.

In foreign practice, the classification proposed by Z.M. Arnez, U. Khan, M.P.H. Tyler in 2009 is the most common[13]. This classification has four types of lesions:

1) limited superficial degloving; there is tissue loss resulting from abrasive force;

2) Non-circumferential degloving; the integumentary tissues are either absent or are flaps. The area of damage is limited to one layer (usually between the deep fascia and subcutaneous fat);

3) Circumferential degloving with an area of tissue damage in single plane;

4) Non-circumferential multi-plane degloving, including trauma to muscles, periosteum, bones.

Chinese authors Hede Yan, Weiyang Gao and other co-authors (Shanghai, China, 2013) [14] proposed their own classification, in which they distinguished 3 main patterns:

- Pattern I - trauma of low grade destruction. This group of degloving consists of two subgroups, depending on the injury: non- circumferential and circumferential tissue damage. The plane of damage is located between the deep fascia and the layer of subcutaneous fat, while there is no injury of the main neurovascular bundles, muscles and bones. It may be open or closed, and skin loss is rare;

- Pattern II - severe injury with involvement of deep soft-tissue layers. This pattern occurs due to higher grade of damage by external energy than in the first group. Deep layers of soft tissue, such as deep fascia and muscles, are damaged, but there are no bone fractures (tibia, fibula, or femur). It is also divided into two subgroups, non-circumferential and circumferential damage. This is regularly usually an open injury, but skin loss is also rare;

- Pattern III - severe trauma with delayed healing of fractures. This pattern is due to the highest grade of energy transfer to the limb. First, this high-energy effect causes deforming lesion of the skin surface, and then it is continuously transferred to deep soft tissues and even long bones, which leads to varying severity of soft tissue lesions and fractures. Basically, it is circumferential tissue damage, and there are frequent extensive abrasions to the skin resulting from friction. There is secondary skin loss due to severe skin contusion.

It should be noted that there are a number of classifications used to assess soft tissue damage in open fractures of long bones. These include the H.G. Tscherne, H.J. Oestern [15], R. Gustilo and J. Anderson [16] classifications, the Hanover fracture scale [17] and classification of soft tissue injuries of the AO system [18].

Developed in 1982, the classification for closed and open fractures by Harald Tscherne and HansJörg Oestern has been often used to define bone and soft tissue injuries. Soft tissue trauma includes rupture of the skin, peripheral contusions, extensive lesions, damage to blood vessels and/or nerves, and amputation of segments. This classification is not suitable for assessing degloving of the integumentary tissues, since there is no damage to the bone tissue in some cases of extensive degloving skin trauma, combined with crushing of the underlying soft tissues.

The AO classification of integumentary tissues degloving seems interesting [18]. The authors have developed a more detailed and accurate classification system for fractures with soft tissue injury. This classification system identifies damage to various anatomical structures and categorizes them into different severity groups. Skin, muscles and tendons, and the vascular system are targeted anatomical structures. Skin lesions are assessed separately for open or closed fractures: the letters " $\mathrm{O}$ " and "C" represent these two categories. Each pattern is divided into 5 groups of severity. Thus, a closed fracture with no visible damage to the skin would be described as IC 1 . The number " 1 " indicates the least injury; IC 5 has the most severe soft tissue damage (Fig. 1).

\section{SOFT TISSUE GRADING SYSTEM OF AO}

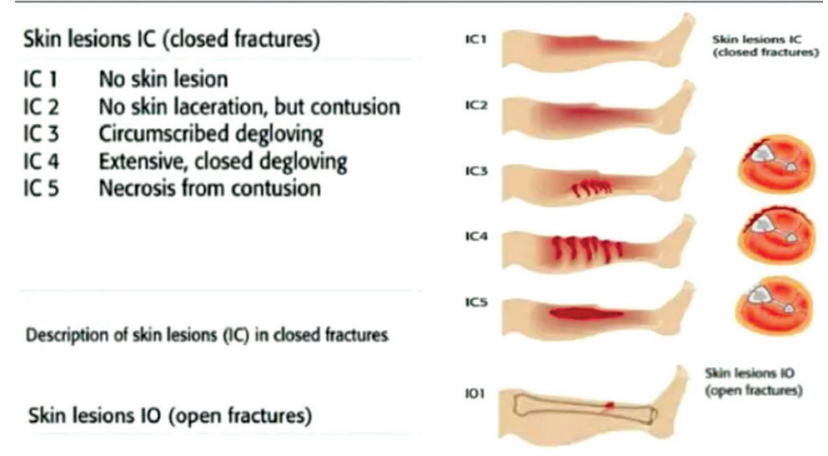

Fig. 1 AO soft tissue grading system [18]

It is obvious, that at present there are not so many proposed classifications of traumatic degloving of 
integumentary tissues, according to the available literature. And they all have some drawbacks:

1) the question of the staging of the pathological process has not been reflected;

2) there is no clear definition of the area of compromised integumentary tissues relative to the entire surface of the human body;

3) some classifications do not reflect damage and crushing of bone, muscle tissue, neurovascular formations;

4) there is no clearly formulated algorithm for treating a patient, depending on the definition of the stage and degree of tissue damage.

We have developed our own classification of extensive degloving based on the clinical manifestations, severity, area and concomitant injuries.

I. Degloving area. For a numerical expression, not absolute numbers are used, but the percentage of damage from the area of the entire surface of the patient's body. This principle has shown its effectiveness in combustiology. To determine the area, you can use G.D. Vilyavin's scheme [19]:

1) up to $2 \%$ (inclusive) of body surface area. The general condition of the patient suffers little (Fig. 2);

2) from 3 to $10 \%$ of the body area (inclusive) (Fig. 3). The patient's condition may be severe due to pain shock; the more distal is the injury, the more significant the pain reaction of the body;

3) more than $11 \%$ of the body area; it corresponds, for example, to the total damage to the integumentary tissues of the lower limb including the gluteal region (Fig. 4). The condition of the patients is characterized by traumatic and hemorrhagic shock even without damage to the great vessels. The general condition of the patient is severe or extremely difficult, requiring resuscitation measures, urgent surgical treatment in order to save patient's life.

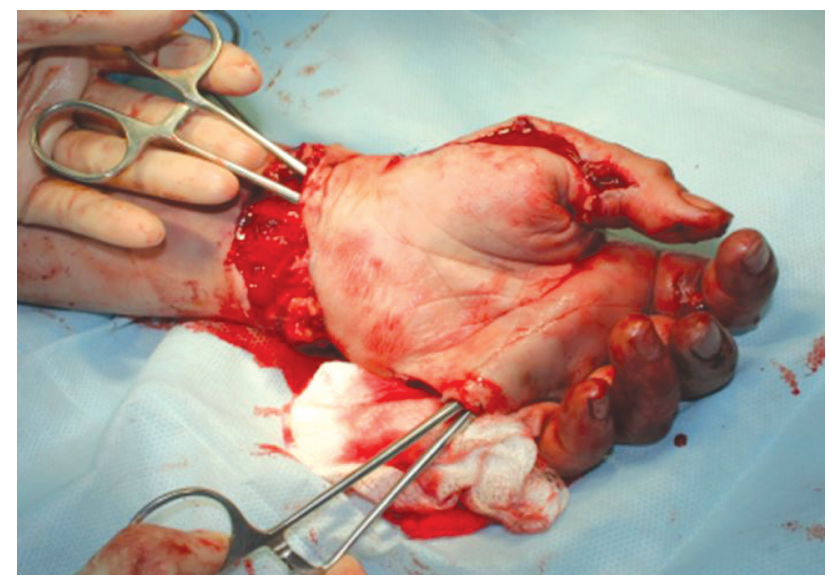

Fig. 2 Intraoperative photo of the left hand of patient S., 32 years old (1st day after injury). Diagnosis: circumferential traumatic degloving of the integumentary tissues of the palmar and dorsum of the metacarpus, closed fractures of the bases of the proximal phalanges of the $2^{\text {nd }}$ and $3^{\text {rd }}$ fingers. Degloving area $1.5 \%$

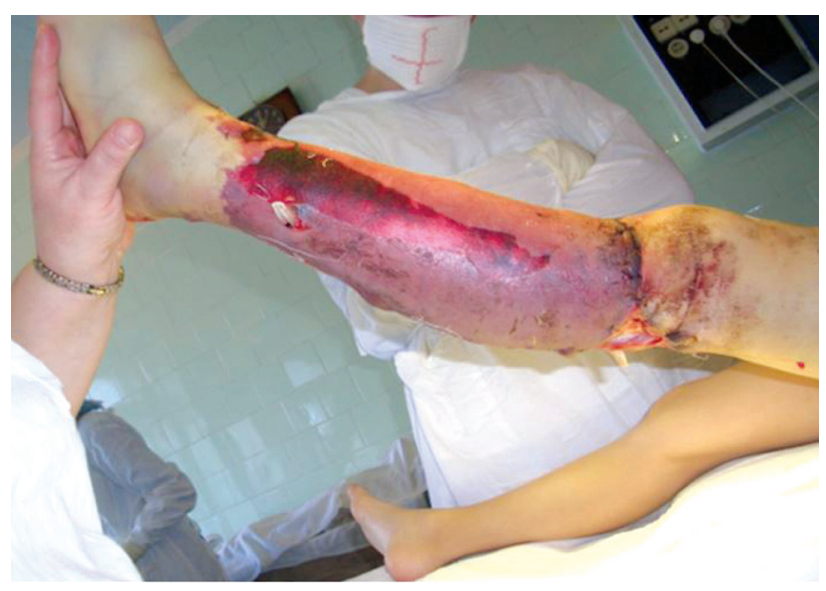

Fig. 3 Intraoperative photo of the damaged area in patient K., 10 years old ( $4^{\text {th }}$ day after injury). Diagnosis: extensive circumferential traumatic degloving of the integumentary tissues of the left leg with crushing of the muscles of the anterior and lateral surface of the leg. Open transverse fracture of the diaphysis of the left tibia. Damaged area $5 \%$

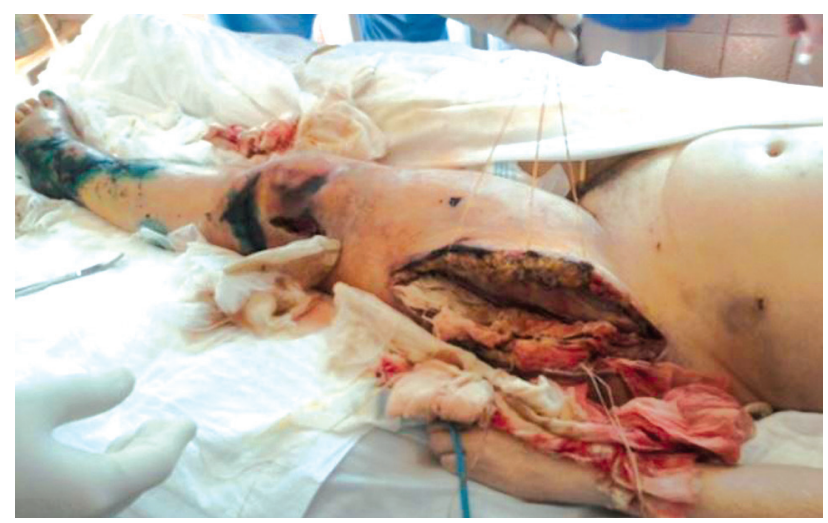

Fig. 4 Intraoperative photo of the injury zone in patient K., 55 years old $\left(19^{\text {th }}\right.$ day after injury). Diagnosis: polytrauma, grade 2 hemorrhagic shock, extensive open degloving of soft tissues of the left lower extremity (foot, lower leg, thigh), left gluteal region, anterior abdominal wall in the iliac, inguinal and left lumbar regions. The total lesion area was $30 \%$ of the body surface

\section{Skin damage:}

1) open;

2) closed (Morel-Lavallée syndrome).

III. Depth of tissue damage (skin, subcutaneous fat, fascia, muscles, bones, neurovascular formations):

1) skin and subcutaneous fat (Fig. 5);

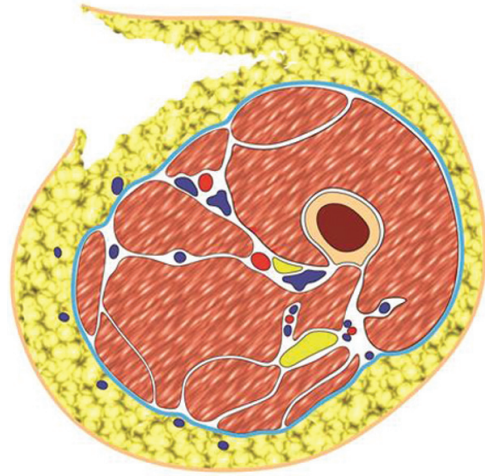

Fig. 5 Damage to integumentary tissues involving the skin and subcutaneous fat. Sections are at the level of the middle third of the thigh. Authors' diagram 
2) skin, subcutaneous fat and superficial fascia (Fig. 6);

3) integumentary tissues and muscle crushing (Fig. 7);

4) degloving of integumentary tissues, combined with damage to muscles, neurovascular formations, bone tissue (fracture, bone defect) (Fig. 8).

IV. Location of injury (upper limbs, lower limbs, trunk, head, combined location).

V. Trauma Index (J.R. Kirkpatric, R.L. Youmans, 1971) [20].

VI. Stages of the pathological complex of symptoms that develop in extensive degloving of integumentary tissues:

1) Stage of alteration (contusion, contamination, bleeding). Acute lesion - up to 1 day. Edema of tissues and paranecrotic processes in ischemic tissues develop;

2) Stage of deep ischemia (partial recanalization, formation of cavities for the deposition of exudate, increase in endogenous intoxication, early infectious complications). Non-acute lesion - from 1 to 4 days;

3) Stage of necrotic changes and infectious complications (from 5 to 20 days). Formation of necrosis and demarcation, development of an infectious process: purulent-resorptive fever, abscess formation in the cavities of exudate accumulation, development of phlegmon, sepsis;

4) Stage of cleansing and scarring. Subsiding of the infectious process due to the formation of callus wounds and pockets lined with dense cicatricle granulation tissue, wound exhaustion, amyloid lesion of internal organs when the process is delayed for more than 2 months;

5) Stage of convalescence. Restoration of integumentary tissues, possible formation of cicatricial contractures of the joints, development of chronic lymphostasis, chronic venous stasis, trophic disorders, secondary ulceration.

Based on the proposed classification, we have developed a checklist that takes into account all these criteria. Having filled it in and calculating the number of points, we determined the severity of integumentary tissues degloving, considering the general condition of the victim (Table 1).

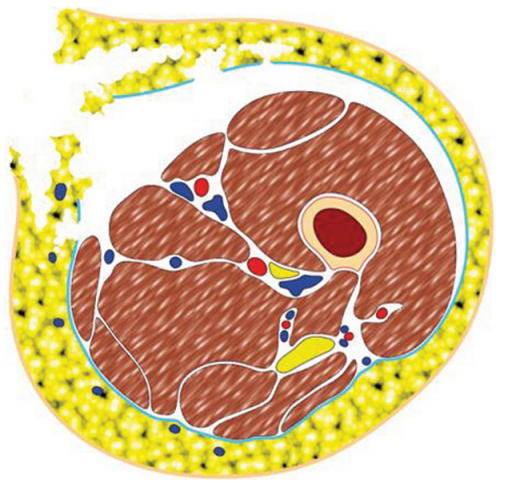

Fig. 6 Damage to the skin, subcutaneous fat and superficial fascia. The bottom of the wound is muscle tissue without crushing. Sections are at the level of the middle third of the thigh. Authors' diagram

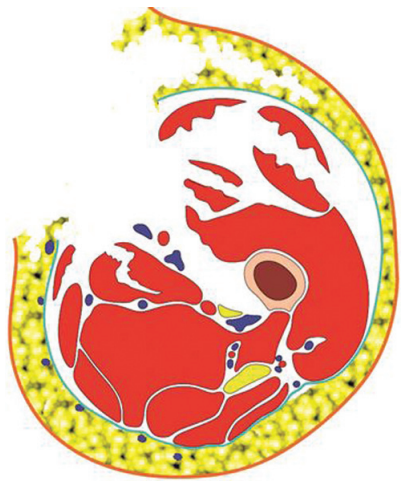

Fig. 7 Damage to the skin, subcutaneous fat, superficial fascia, crushing and muscle tissue defect. Sections are at the level of the middle third of the thigh. Authors' diagram

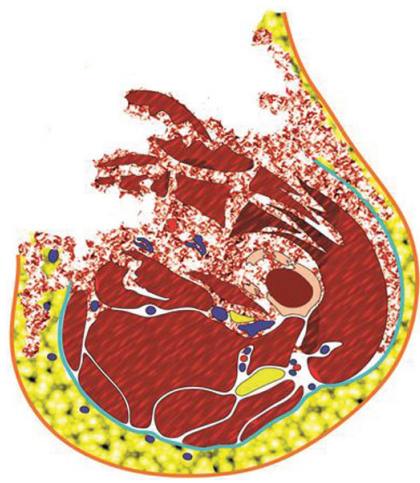

Fig. 8 Damage to the skin, subcutaneous fat, superficial fascia, crushing and muscle tissue defect, fracture of the bones of the segment. Injury of the neurovascular trunks is possible. Sections are at the level of the middle third of the thigh. Authors' diagram

Table 1

Score system for evaluating the severity of tissue degloving

\begin{tabular}{|c|c|c|c|}
\hline & Parameter & Criteria & Number of points \\
\hline \multirow{3}{*}{ I. } & \multirow{3}{*}{ Area of body injury } & Up to $2 \%$ & 1 \\
\hline & & from 3 to $10 \%$ & 2 \\
\hline & & More than $11 \%$ & 3 \\
\hline \multirow{2}{*}{ II. } & \multirow{2}{*}{ Skin lesions } & Closed (Morel-Lavallée syndrome) & 1 \\
\hline & & Open & 2 \\
\hline \multirow{4}{*}{ III. } & \multirow{4}{*}{$\begin{array}{l}\text { Tissue injury } \\
\text { deepness }\end{array}$} & Skin and subcutaneous fat & 1 \\
\hline & & Skin, subcutaneous fat and superficial fascia & 2 \\
\hline & & Integumentary tissue and muscle crushing & 3 \\
\hline & & $\begin{array}{l}\text { Crush injury to all tissue layers, including neurovascular formation, bone (fracture, } \\
\text { bone defect) }\end{array}$ & 4 \\
\hline \multirow{3}{*}{ IV. } & \multirow{3}{*}{$\begin{array}{l}\text { Specific location of } \\
\text { injury }\end{array}$} & Hand & 1 \\
\hline & & Perineum & 2 \\
\hline & & Head & 3 \\
\hline \multirow{3}{*}{ V. } & \multirow{3}{*}{$\begin{array}{l}\text { Trauma Index } \\
\text { (Kirkpatric J.R., } \\
\text { Youmans R.L., 1971) }\end{array}$} & Minimal injury, 1-2 points & 1 \\
\hline & & Moderate injury, 3-4 points & 2 \\
\hline & & Severe injury, 5-6 points & 3 \\
\hline Total & & & \\
\hline
\end{tabular}


Thus, the severity of injury, involving degloving of the integumentary tissues, would be graded as follows:
1) mild type: 4-6 points;

2) moderate severity: $7-10$ points;

3) severe type: $11-15$ points.

\section{CONCLUSION}

The presented classification reflects the area, depth the patient and the stage of the pathological process. of tissue damage, localization, general condition of It can be used in clinical practice.

The authors of this work declare that there are no obvious and potential conflicts of interest associated with the publication of this work.

The study was not sponsored.

\section{REFERENCES}

1. Bordakov V.N., Elin I.A., Bordakov P.V., Savitskii D.S., Sukharev A.A., Doronin M.V., Ezerskii K.F. Travmaticheskaia otsloika miagkikh tkanei: diagnostika i lechebnaia taktika [Traumatic detachment of soft tissues: diagnosis and treatment tactics]. Ekstrennaia Meditsina, 2015, no. 3 (15), pp. 112-120. (in Russian)

2. Belenkii I.G., Spesivtsev A.Iu., Imshennik O.V., Ramade U.A. Zakrytaia travmaticheskaia otsloika kozhi: printsipy diagnostiki i lecheniia [Closed traumatic skin detachment: principles of diagnosis and treatment]. Ambulatornaia Khirurgiia, 2004, no. 1, pp. 38-40. (in Russian)

3. Korostelev M.Iu., Shikhaleva N.G. Sovremennoe sostoianie problemy lecheniia patsientov s obshirnymi otsloikami pokrovnykh miagkikh tkanei (obzor literatury) [Current state of treating patients with extensive degloving injuries of integumentary soft tissues (literature review)]. Genij Ortopedii, 2017, vol. 23, no. 1, pp. 88-94. DOI 10.18019/1028-4427-2017-23-1-88-94

4. Petrov Iu.L., Korostelev M.Iu., Shikhaleva N.G. Klinicheskii primer lecheniia patsientki s obshirnoi travmaticheskoi otsloikoi miagkikh tkanei [A clinical example of treating a female patient with extensive traumatic detachment of soft tissues]. Politravma, 2019, no. 4, pp. 58-65. (in Russian)

5. Mello D.F., Assef J.C., Soldá S.C., Helene A. Jr. Degloving injuries of trunk and limbs: comparison of outcomes of early versus delayed assessment by the plastic surgery team. Rev. Col. Bras. Cir., 2015, vol. 42, no. 3, pp. 143-148. DOI: 10.1590/0100-69912015003003

6. Wójcicki P., Wojtkiewicz W., Drozdowski P. Severe lower extremities degloving injuries - medical problems and treatment results. Pol. Przegl. Chir., 2011, vol. 83, no. 5, pp. 276-282. DOI: 10.2478/v10035-011-0043-3

7. Antoniou D., Kyriakidis A., Zaharopoulos A., Moskoklaidis S. Degloving Injury. Eur. J. Trauma, 2005, vol. 31, pp. 593-596. DOI: 10.1007/s00068005-1059-3

8. Carroll J.F. Morel-Lavallee Lesions. Radsource LLC. MRI Web Clinic, 2010. Available at: http://www.radsource.us/clinic/1006

9. Mikusev I.E., Mikusev G.I., Khabibullin R.F. Travmaticheskaia otsloika kozhi: voprosy diagnostiki i lecheniia [Traumatic skin detachment: problems of diagnosis and treatment]. Prakticheskaia Meditsina, 2013, vol. 2, no. 1-2 (69), pp. 104-107. (in Russian)

10. Krasovitov V.K. Pervichnaia plastika ottorgnutymi loskutami kozhi (s dobavleniem lit. obzora autoplastiki) [Primary plasty with rejected skin flaps (with addition of review of the literature on autoplasty)]. Krasnodar, Krasnodarskoe Kraevoe Knigoizd-vo, 1947,239 p. (in Russian)

11. Proshakov A.A., Petrov V.G., Chizhenkov G.A., Kozlov S.E. Travmaticheskaia otsloika kozhi [Traumatic skin detachment]. Ortopediia, Travmatologiia i Protezirovanie, 1987, no. 11, pp. 18-21. (in Russian)

12. Hidalgo D.A. Lower extremity avulsion injuries. Clin. Plast. Surg., 1986, vol. 13, no. 4, pp. 701-710.

13. Arnez Z.M., Khan U., Tyler M.P. Classification of soft-tissue degloving in limb trauma. J. Plast. Reconstr. Aesthet. Surg., 2010, vol. 63, no. 11, pp. 1865-1869. DOI: 10.1016/j.bjps.2009.11.029

14. Yan H., Liu S., Gao W., Li Z., Chen X., Wang C., Zhang F., Fan C. Management of degloving injuries of the foot with a defatted full-thickness skin graft. J. Bone Joint Surg. Am., 2013, vol. 95, no. 18, pp. 1675-1681. DOI: 10.2106/JBJS.L.01085

15. Tscherne H., Oestern H.J. Die Klassifizierung des Weichteilschadens bei offenen und geschlossenen Frakturen [A new classification of soft-tissue damage in open and closed fractures (author's transl)]. Unfallheilkunde, 1982. Vol. 85, No 3. P. 111-115. (in German)

16. Gustilo R.B., Mendoza R.M., Williams D.N. Problems in the management of type III (severe) open fractures: a new classification of type III open fractures. J. Trauma, 1984, vol. 24, no. 8, pp. 742-746. DOI: 10.1097/00005373-198408000-00009

17. Suedkamp N.P., Barbey N., Veuskens A., Tempka A., Haas N.P., Hoffmann R., Tscherne H. The incidence of osteitis in open fractures: an analysis of 948 open fractures (a review of the Hannover experience). J. Orthop. Trauma, 1993, vol. 7, no. 5, pp. 473-482. DOI: 10.1097/00005131-199310000-00011

18. Rüedi T.P., Buckley R., Moran C.G. AO Principles of Fracture Management. Rev. by S. Hodgson. Stuttgart: Thieme, 2007,1106 p.

19. Petrov S.V. Obshchaia Khirurgiia. Ucheb. posobie dlia studentov [med.] VUZov [General Surgery. Manual for students of (medical) Academies]. SPb., Lan, 1999, 237 p. (in Russian)

20. Kirkpatric J.R., Youmans R.L. Trauma index. An aide in the evaluation of injury victims. J. Trauma, 1971, vol. 11, no. 8, pp. 711-714.

Received: 31.08 .2020

\section{Information about the authors:}

1. Mikhail Yu. Korostelev, M.D., Ilizarov National Medical Research Centre for Traumatology and Orthopedics, Kurgan, Russian Federation, Email: 2351724@mail.ru

2. Natalia G. Shikhaleva, M.D., Ph.D.,

Ilizarov National Medical Research Centre for Traumatology and Orthopedics, Kurgan, Russian Federation,

Email: nshihaleva@mail.ru

3. Oleg V. Klimov, M.D., Ph.D.,

Ilizarov National Medical Research Centre for Traumatology and Orthopedics, Kurgan, Russian Federation,

Email: oklim@mail.ru 